\title{
CONTRIBUIÇÃO AO ESTUDO GEOQUÍMICO E TECTÔNICO DA GRANITOGÊNESE BRASILIANA NO ESTADO DO RIO DE JANEIRO
}

R.Machado ${ }^{1}$

M.Demange ${ }^{2}$

O Cinturão Ribeira, estendendo-se por toda costa Atlântica Sul-Sudeste brasileira, com cerca de 2.000 km de extensão (do Espírito Santo ao Rio Grande do Sul), é caracterizado por extensas exposições (cerca de $25 \%$ em área) de maciços graníticos lineares. Muitos destes maciços possuem dimensões batolíticas, características $\sin$ a tardi-orogênicas, tendo sido desenvolvidos durante o ciclo brasiliano, com estruturação geral NE-SW.

No Estado do Rio de Janeiro, os maciços graníticos são classificados em função de seus domínios estruturais, do nivel estrutural de colocação, das relações entre metamorfismo e deformação, da correlação entre as associações petrográficas e os dados geoquímicos.

São reconhecidos quatro domínios estruturais, dispostos de SE para NW na seguinte ordem (das zonas internas em direção às zonas externas): (i) Litorâneo (Norte e Sul); (ii) Serra dos Órgãos; (iii) Paraíba (Norte e Sul) e, (iv) Juiz de Fora. Estes domínios são separados entre si por importantes zonas de cisalhamento dúcteis.

Das quatro fases de deformações reconhecidas regionalmente no Rio de Janeiro, pelo menos as três últimas foram acompanhadas pela colocação de granitos. A fase F2 ( 600 Ma.), associada a grandes cavagalmentos, foi responsável pela geração de granitos foliados, em maciços lineares, de dimensões batoliticas, colocados em nivel crustal profundo (fácies anfibolito e granulito), com ou sem associação charnockítica, do tipo Cordilherano (Bela Joana, Angelim, Niterói, Serra dos Órgãos) ou do tipo Hercínico (Serra das Araras, Turvo). A fase F3 ( 550 Ma.), associada às zonas de

${ }^{1}$ Departamento de Geologia Geral, Instituto de Geociências, USP.

2École des Mines de Paris, França. 
cisalhamento dúcteis de alto ângulo do vale do Rio Paraíba do Sul, foi também acompanhada pela colocação de maciços graníticos foliados, alongados, porém de dimensões mais reduzidas do que os da fase anterior, seja como stocks ou como pequenos batólitos, de composição granficica a granodioritica, de colocação em nível de fácies anfibolito/xisto verde alto (Vassouras, Getulândia...). Os corpos granfticos tardi-F3 a sin-F4 ( $500 \mathrm{Ma}$.) ocorrem em pequenos maciços, isótropos, não foliados internamente, de colocação mais rasa do que os das fases precedentes, em ambiente do tipo extensional, caracterizando magmatismo do tipo-l (Sana, Nova Friburgo, Frades, São José do Ribeirão...), por vezes com zoneamento inverso (Pedra Branca), tendo arcabouço de composição granftica a monzogranftica com enclaves básicos (monzodiorticos, quartzo-monzodiorticos a granodiorticos). Ainda nesta fase, incluem-se granitos a muscovita e/ou granada (Morro do Coco, Utinga, Favela, Andorinha).

As associações petrográficas e os dados geoquímicos permitem definir diferentes linhas magmáticas de características meta-aluminosas que incluem termos cálcio-alcalinos (com associação de quartzo-diorito, tonalito, granodiorito, monzogranito ou em fácies granulito com associação enderbito, opdalito e charnockito), gerados em regime compressional, seguidos por granitóides tipo-S, em regime colisional e, finalmente, por granitóides tipo-l, já em regime extensional.

A granitogênese brasiliana do Cinturão Ribeira no Estado do Rio de Janeiro desenvolveu-se no intervalo de 500-600 Ma. (dados $\mathrm{Rb} / \mathrm{Sr}$ ), com um sugestivo zoneamento magmático, indo de termos cálcío-alcalinos mais cálcicos nas porções internas, a SE, até termos mais potássicos nas porções externas, a NW. Estas características também são observadas no Cinturão Dom Feliciano, no Rio Grande do Sul, através do Batólito Pelotas.

Este zoneamento magmático mostrado pelo Cinturão Ribeira na altura do Rio de Janeiro, juntamente com a estruturação tectônica divergente aí observada, sugere um modelo de evolução semelhante ao das cadeias orogênicas modernas do tipo margem continental ativa, como a dos Andes, por exemplo (sobretudo da seção Peruana), porém com maior maturidade magmática e representando um nivel estrutural inferior - as "raízes" de um sistema orogênico deste tipo. Este modelo sugere uma zona de subducção mergulhando por debaixo do Cinturão Ribeira para NW. Este mesmo modelo pode também ser aplicado para o Cinturão Dom Feliciano no RS e Uruguai, pois nele repetem-se os mesmos tipos de zoneamento magmático e polaridade orogênica. 